\title{
EFEKTIVITAS PEMBELAJARAN DARING PADA MATA KULIAH KEMAHIRAN BERBICARA BAHASA ARAB DI UNIVERSITAS AL AZHAR INDONESIA
}

\author{
Ghina Kania Rahmah ${ }^{1}$ \\ ${ }^{1}$ Universitas Al Azhar Indonesia, Jakarta \\ *Corresponding Address: ghinakaniabarbie@gmail.com
}

Naskah diterima: 9 Desember 2021| Disetujui: 22 Desember 2021 | Diterbitkan: 23 Desember 2021

\begin{abstract}
This study discusses the level of effectiveness of online methods in improving understanding and speaking Arabic skills in Arabic speaking proficiency courses at Al-Azhar University, Indonesia during the covid 19 pandemic. The data used in this study refers to the response of students from class 2019 to online learning in Arabic speaking proficiency courses by using technological media from the internet or several applications such as Zoom, WhatsApp and so on. The purpose of this study was to determine the effectiveness of online learning in Arabic speaking proficiency courses for Arabic Literature Students, Al-Azhar University, Indonesia. The method used in this study is the Pearson Correlation method with a questionnaire technique. The results of this study are that the implementation of online learning in Arabic speaking proficiency courses at Al-Azhar University Indonesia is quite effective in improving understanding and speaking Arabic skills, and the students feel very helpful with the use of available technological media.
\end{abstract}

Keywords: Online Learning, Speaking Proficiency, Arabic Language, Covid 19

\begin{abstract}
Abstrak: Penelitian ini membahas mengenai tingkat keefektifan metode daring (online) dalam meningkatkan pemahaman dan kemahiran berbicara bahasa Arab pada mata kuliah Kemahiran Berbicara Bahasa Arab di Universitas Al Azhar Indonesia selama pandemi Covid-19. Data yang digunakan merujuk kepada respon mahasiswa angkatan 2019 terhadap pembelajaran daring (online) yang dilaksanakan dengan menggunakan media teknologi internet atau beberapa aplikasi seperti Zoom, WhatsApp, dan lain sebagainya. Tujuan penelitian ini adalah untuk mengetahui efektifitas pembelajaran daring (online) pada mata kuliah Kemahiran Berbicara Bahasa Arab bagi mahasiswa sastra Arab Universitas Al Azhar Indonesia. Metode yang dilakukan dalam penelitian ini adalah Pearson Correlation dengan teknik kuesioner. Adapun hasil dari penelitian ini adalah cukup efektif dalam meningkatkan pemahaman dan kemahiran berbicara bahasa Arab, serta peserta didik merasa sangat terbantu dengan penggunaan media teknologi yang tersedia.
\end{abstract}

Kata kunci: Pembelajaran Daring, Kemahiran Berbicara, Bahasa Arab, Covid-19 


\section{PENDAHULUAN}

Sebanyak 215 negara di dunia terserang wabah virus Covid-19 (Corona Virus Disease). Peristiwa ini mengubah sedikit banyak situasi dan aktifitas di lembaga pendidikan, khususnya perguruan tinggi. Demi melawan Covid-19, pemerintah Indonesia telah memberikan himbauan untuk tidak berkerumun, menjaga jarak fisik (physical distancing), selalu memakai masker, dan rajin cuci tangan (Sadikin \& Hamidah, 2020). Di tengah masa pademi, pemerintah membuat keputusan untuk melakukan lock down dan karantina di wilayah Indonesia. Masyarakat diharap untuk selalu berada di rumah agar virus ini tidak menyebar.

Pemerintah meliburkan sekolah, perkuliahan, dan perkantoran dengan tujuan membatasi aktivitas yang bertatap muka dan mengganti dengan mengerjakan tugas dari rumah yang diberikan oleh guru, dosen, maupun atasan kerja atau yang dikenal dengan Work From Home. Pemerintah juga mengalihkan kegiatan belajar mengajarnya dengan istilah pembelajaran jarak jauh atau kuliah daring (online) untuk memutus rantai penyebaran virus Covid-19. Situasi belajar-mengajar berubah dengan cepat. Baik guru maupun siswa perlu beradaptasi untuk menyesuaikan diri dengan situasi ini. Akan tetapi, perubahan yang sangat cepat ini menyebabkan krisis di mana semua guru dan siswa mengalami kelelahan yang mendalam.

Hal ini disebabkan oleh sistem belajar mengajar yang telah berubah menjadi pembelajaran online. Pembelajaran online berarti ada waktu khusus untuk menatap layer dan membutuhkan lebih banyak fokus dan motivasi, akan tetapi juga menyebabkan lebih banyak penundaan (Syahputri et al., 2020). Pandemi ini juga berdampak parah pada pendidikan tinggi karena harus ditutup selama lock down. Meskipun organisasi pendidikan tinggi bergegas untuk melakukan pembelajaran berbasis online, penghentian ini memengaruhi pembelajaran dan penilaian bagi tenaga pengajar dan siswa di negara manapun. Agar subtansi pendidikan tetap relevan, universitas perlu membentuk kembali lingkungan belajar, sehingga digitalisasi dapat meluas dan melengkapi hubungan antara mahasiswa dan dosen, juga dengan civitas akademika yang lain.

Komunikasi daring (dalam jaringan) merupakan cara berkomunikasi di mana penyampaian dan penerimaan pesan dilakukan dengan atau melalui jaringan internet atau melalui dunia maya (cyberspace). Komunikasi virtual pada abad ini dapat dilakukan di mana saja dan kapan saja. Menurut Kamus Besar Bahasa Indonesia (KBBI) kata daring (online) berarti dalam jaringan, terhubung melalui jejaring komputer, internet, dan sebagainya (KBBI; Daring). Menurut Warschauer, istilah komunikasi daring (online) mengacu pada membaca, menulis, dan berkomunikasi melalui atau menggunakan jaringan komputer (Warschauer, 2001). 
Revolusi teknologi digital yang dikenal dengan istilah communication network dalam bidang informasi dan telekomunikasi mulai berkembang sejak tahun 1970-an. Perkembangan ini menciptakan surat elektronik yang mampu menstransfer data dalam bentuk teks, gambar, dan video dalam satu lapisan yang kompleks. Selanjutnya pada tahun 1990-an, media sosial mulai bermunculan (Warschauer, 2001). Media sosial adalah salah satu media yang dapat digunakan secara daring (online) yang memudahkan para penggunanya berkomunikasi antar muka, berpartisipasi, dan berbagi jarak jauh. Adapun jenis media sosial yang paling populer di Indonesia, antara lain Facebook (FB), WhatsApp (WA), Youtube (Ytb), Instagram (Ig), Twitter (Twt), dan aplikasi Zoom.

Pandemi covid-19 telah membuat sistem pendidikan dunia bermanuver. Situasi belajarmengajar berubah dengan cepat. Baik guru maupun siswa perlu beradaptasi dengan cepat untuk menyesuaikan diri dengan situasi ini. Namun, perubahan yang sangat cepat menyebabkan krisis di mana semua guru dan siswa mengalami perubahan yang drastis. Hal ini karena sistem belajar mengajar telah berubah menjadi dari pembelajaran tatap muka menuju pembelajaran online pada tahap lengkap.

Adapun beberapa kelebihan pembelajaran melalui daring (online) yaitu pembelajaran dapat dilakukan kapanpun dan di mana saja, lebih menghemat biaya transportasi, serta komunikasi dapat disampaikan secara langsung dalam hitungan detik walaupun berada di lokasi yang berbeda dan berjauhan. Pembelajaran online memiliki keleluasaan dalam pelaksanaannya dan mampu mendorong perilaku social distancing, dapat mengurangi potensi penyebaran Covid-19 di lingkungan kampus, serta menghilangkan perasaan canggung sehingga mahasiswa dapat mengemukakan ide, pendapat, dan bertanya secara bebas (Iqbal \& Sohail, 2021).

Adapun kekurangannya, yaitu peserta didik tidak mendapatkan materi fisik secara langsung seperti mencatat pelajaran di kelas, bertanya di dalam kelas, dan kurangnya daya tarik bagi mereka untuk mengadakan pembelajaran secara daring tersebut. Selain itu, tidak ada hubungan yang signifikan antara kepuasan guru untuk terus menggunakan teknologi e-learning. Hal yang termasuk kelemahan dalam infrastruktur kuliah online adalah kurangnya pengalaman guru (termasuk hasil belajar yang tidak seimbang yang disebabkan oleh pengalaman guru yang beragam), kesenjangan informasi, kesulitan lingkungan yang kompleks di rumah, kurangnya disiplin, proses pendidikan online yang kurang efektif, dan pengajaran online jangka panjang dapat menyebabkan dampak negatif terhadap kesehatan mental dan fisik siswa (Dafalla \& Ahmed, 2017).

Pembelajaran daring merupakan suatu pendekatan untuk memfasilitasi dan meningkatkan pembelajaran melalui komputer pribadi, CDROM, dan internet, termasuk juga email, forum diskusi, dan kolaborasi perangkat lunak. Keuntungan terlihat bahwa pembelajaran dimungkinkan selesai tepat 
waktu, kursus dapat disesuaikan dengan kebutuhan khusus dan pembelajaran asinkronus dapat dilakukan (Churton, 2006). Kegiatan pembelajaran jarak jauh yang dilaksanakan secara online tentu sangat didukung oleh situasi pandemi seperti ini.

Keterampilan berbicara merupakan salah satu tujuan terpenting dari pembelajaran bahasa Arab. Penekanan pada kecakapan lisan tidak dan seharusnya tidak berarti bahwa bidang keterampilan lain harus diabaikan dalam komunikasi bahasa. Namun, sebagai bagian dari tujuan pengajaran bahasa Arab adalah agar cakap dalam keterampilan berbicara bahasa Arab, guru bahasa Arab berkewajiban untuk mengidentifikasi strategi yang efektif untuk mengajarkan keterampilan ini untuk mencapai tingkat kemahiran yang diperlukan (Yaqub, 2012).

Kemahiran berbicara bahasa Arab tidak selalu disertai dengan upaya dalam mewujudkan keaktifan mahasiswa dalam berbicara bahasa Arab tersebut. Meskipun beberapa lembaga telah berusaha mewujudkan upaya tersebut, akan tetapi hasilnya belum dapat diketahui dengan pasti sehingga lembaga lainnya tidak dapat mengikuti metode dan upaya yang dilakukan oleh lembaga tersebut (Marlius et al., 2021). Apalagi dalam kondisi pandemi seperti ini di mana akses pembelajaran secara langsung lebih terbatas, maka lembaga perguruan tinggi membutuhkan upaya yang lebih besar demi mencapai efektifitas pembelajaran dalam meningkatkan kemahiran berbahasa Arab.

Dalam prakteknya, pembelajaran bahasa Arab memiliki unsur esensial yang ditekankan, yaitu peningkatan kemampuan berbahasa yang tidak boleh dihentikan. Situasi pandemi seperti sekarang ini turut mengubah proses pembelajaran bahasa Arab ke penggunaan media online dengan tujuan mewujudkan keterlibatan aktif siswa dalam pembelajaran (Wargadinata, 2020). Untuk pembelajar bahasa Arab, pembelajaran bahasa aktif adalah pendekatan pertama yang harus dilakukan. Maka dalam keadaan apapun pembelajaran bahasa harus tetap berjalan dan keterampilan berbahasa juga harus diwujudkan dengan sebaik-baiknya.

Latar belakang yang dibawa pembelajar ke situasi belajar, pembelajaran, dan strategi komunikasi yang mereka terapkan mempengaruhi kemampuan belajar siswa dalam proses pembelajaran bahasa dan metode pengembangan kemahiran bahasa (Haron, 2012). Pembelajar bahasa yang sukses tampaknya memiliki pandangan yang lebih luas tentang pembelajaran bahasa daripada pembelajar yang kurang berhasil. Pembelajar yang berhasil percaya bahwa pembelajaran bahasa memerlukan perhatian baik fungsi maupun bentuk, termasuk kosa kata, morfologi, dan tata bahasa, sedangkan pelajar yang kurang berhasil percaya bahwa suatu bahasa terutama terdiri dari satu set kata-kata yang dapat dirangkai untuk berkomunikasi.

Pembelajaran bahasa Arab di Indonesia bertujuan untuk mencapai dua hal. Pertama, sebagai alat untuk mendalami ajaran Islam, seperti di madrasah, pesantren, dan perguruan tinggi Islam. 
Kedua, menghasilkan ahli bahasa Arab yang dapat menggunakan bahasa Arab secara aktif sebagai alat komunikasi dalam berbagai kebutuhan (Rosyadi \& Ilmi, 2021). Dalam hal ini, perguruan tinggi diharapkan dapat memberikan fasilitas dan akses yang memadai untuk mencapai tujuan pembelajaran bahasa Arab tersebut.

Salah satu pembelajaran daring dalam mata kuliah kemahiran berbicara bahasa Arab di Indonesia dilaksanakan oleh Universitas Al Azhar Indonesia, tepatnya di Program Studi Bahasa dan Kebudayaan Arab yang memiliki mata kuliah kemahiran berbicara bahasa Arab. Kemahiran berbicara bahasa Arab (muhadatsah) dalam pembelajaran bahasa Arab termasuk keterampilan dasar yang harus dikuasai oleh peserta didik dan merupakan salah satu tujuan akhir pembelajaran bahasa asing. Pembelajaran bahasa Arab dengan daring (online) menjadi sebuah terobosan alternatif dalam pembelajaran bahasa Arab di tengah pademi virus Covid-19 yang terjadi di Indonesia.

Dalam pembelajaran kemahiran berbicara bahasa Arab, semakin banyak yang mengamalkan apa yang dipelajari, semakin membantu memperkuat kemampuan. Proses memperoleh kemahiran dimulai dengan minat peserta didik terhadap suatu ilmu tertentu. Ketika pelajar terus berlatih dan mengulangi kosakata bahasa Arab dan menyampaikan kalimat-kalimat berbahasa Arab, tentu akan menjadi lebih cakap dalam berbicara bahasa Arab, dapat beradaptasi sepenuhnya, dan menjadi kebiasaan bagi pelajar. Pada tahap ini, pengetahuan siswa akan kosakata dan ucapan berbahasa Arab disebut sebagai kemampuan, yang juga berarti keterampilan atau penguasaan (Haron, 2012). Selain itu, seorang mahasiswa Program Studi Bahasa dan Kebudayaan Arab harus memiliki minat atau motivasi yang kuat untuk menjadi penutur bahasa Arab yang baik.

Saat ini, tantangan untuk mengakses pembelajaran online lebih sedikit karena pembelajar dan guru telah mengalami peluang yang sangat baik untuk mengetahui dan berinteraksi dengan perangkat teknologi pendidikan, seperti pembelajaran berbasis seluler, pembelajaran berbasis komputer, dan pembelajaran berbasis web (Mahyoob, 2020). Kelebihan dari kuliah daring (online) ini memungkinkan dosen memberikan perkuliahan secara langsung seperti di dalam kelas, melalui video conference atau rekaman untuk memudahkan peserta didik bahasa Arab. Selain itu, pembelajaran daring (online) memberi kesempatan bagi peserta didik untuk mengulang kembali video atau rekaman pembelajaran apabila ada materi yang dilewatkan atau sulit untuk dipahami.

Dari uraian di atas, dapat disimpulkan bahwa kuliah daring (online) dari waktu ke waktu semakin berkembang. Pada penelitian kali ini, penulis ingin mengetahui bagaimana respon mahasiswa terhadap pembelajaran kemahiran berbicara bahasa Arab secara daring (online) di Universitas Al-Azhar Indonesia. Pertanyaan yang dirumuskan dalam penelitian ini adalah bagaimana 
tingkat efektifitas pembelajaran daring dalam mata kuliah Kemahiran Berbicara Bahasa Arab bagi mahasiswa Al-Azhar Indonesia.

\section{METODE}

Tujuan dari peneltian ini adalah untuk mengetahui tingkat efektifitas pembelajaran daring dalam mata kuliah Kemahiran Berbicara Bahasa Arab di Universitas Al-Azhar Indonesia, menjelaskan seberapa besar pengaruh pembelajaran secara daring dalam mata kuliah Kemahiran Berbicara Bahasa Arab. Objek dari penelitian ini adalah 33 mahasiswa dan mahasiswi Program Studi Bahasa dan Kebudayaan Arab Universitas Al-Azhar Indonesia angkatan 2019 yang mengikuti mata kuliah Kemahiran Berbicara Bahasa Arab tingkat menengah.

Metode yang digunakan untuk penyidikan dan pengumpulan data dalam penelitian ini adalah metode kuesioner melalui google form yang dilakukan secara online. Kuesioner dibagikan kepada mahasiswa dan mahasiswi Program Studi Bahasa dan Kebudayaan Arab Universitas Al-Azhar melalui link yang telah dibuat oleh penulis untuk kemudian diisi oleh masing-masing responden. Dalam mengisi angket, metode yang digunakan adalah metode Likert, yaitu metode yang memaksa seorang memilih salah satu pilihan. Metode ini dipilih karena merupakan metode yang paling mudah dan sederhana.

Data yang diperoleh kemudian dianalisis menggunakan metode Pearson Correlation. Metode Pearson Correlation adalah salah satu jenis dari metode korelasi. Metode korelasi adalah suatu metode statistik yang digunakan untuk menilai kemungkinan hubungan linier antara dua variabel kontinu. Ada dua jenis utama koefisien korelasi, yaitu korelasi pearson (Person Correlation) dan koefisien korelasi peringkat Spearman. Korelasi Pearson (Person Correlation) digunakan ketika kedua variabel yang diteliti berdistribusi normal. Koefisiennya dipengaruhi oleh nilai-nilai yang dapat menambah atau mengurangi kekuatan hubungan, oleh karena itu tidak tepat jika salah satu atau kedua variabel tidak terdistribusi normal (M.M Mukaka, 2012).Dalam penelitian ini, metode $P$ earson Correlation dilakukan dengan mengukur korelasi dari dua variabel yang tersusun dalam sebuah instrumen kuesioner dengan sistematis. Instrumen kuesioner dalam penelitian ini adalah instrumen dalam bentuk angket. Setiap pertanyaan di dalam angket tersebut memiliki bobot nilai masingmasing.

\section{HASIL DAN PEMBAHASAN}

Ada berbagai definisi yang telah dan sedang digunakan sebagai parameter pembelajaran daring. Poin yang menonjol adalah pertanyaan tentang bagaimana pelaksanaan dari pembelajaran daring tersebut 
dapat didefinisikan, dirancang, dan dipertahankan demi memenuhi kebutuhan pengajar dan peserta didik.

Dalam bentuknya yang paling sederhana, pembelajaran daring merupakan sistem penyampaian instruksional yang menghubungkan peserta didik dengan sumber daya pendidikan. Implementasi pembelajaran daring adalah sebuah proses yang menggunakan sumber daya yang tersedia dan akan berkembang untuk menggabungkan teknologi yang ada (Churton, 2006). Beberapa parameter utama dalam pembelajaran daring adalah pemisahan guru dan siswa selama setidaknya sebagian besar proses pembelajaran, penggunaan teknologi instruksional untuk menyatukan guru dan pelajar dalam menyampaikan konten pembelajaran, penyediaan beberapa komunikasi sinkron antara guru, tutor, dosen, atau lembaga pendidikan dan peserta didik, serta kontrol kehendak belajar oleh siswa dengan instruktur jarak jauh.

Di era komunikasi yang dimediasi komputer, garis antara bahasa lisan dan tulisan tampak agak kurang jelas terutama dalam mode interpersonal (Yaqub, 2012). Sebelum diuraikan persepsi mahasiswa program studi sastra Arab Universitas Al Azhar Indonesia terhadap efektivitas pembelajaran daring pada mata kuliah Kemahiran Berbicara Bahasa Arab di Universitas Al Azhar Indonesia, pemakalah akan menjelaskan pertanyaan-pertanyaan yang diajukan kepada responden. Pertanyaan-pertanyaan ini ditunjukkan pada mahasiswa dan mahasiswi yang sudah berpengalaman belajar dengan menggunakan aplikasi, Zoom, WhatsApp, Youtube, Facebook dan lainnya. Pertanyaan-pertanyaan ini bersifat tertutup. Terdapat enam pertanyaan yang wajib dijawab oleh responden, semuanya bersifat pilihan ganda. Berikut akan pemakalah jelaskan pertanyaan-pertanyaan yang diajukan kepada responden.

Tabel 1. Hasil Responden

\begin{tabular}{|c|c|c|}
\hline No. & Deskripsi Pertanyaan & Jawaban Responden \\
\hline 1 & $\begin{array}{l}\text { Metode pembelajaran dalam mata kuliah } \\
\text { Kemahiran Berbicara Bahasa Arab yang biasa } \\
\text { diterapkan dosen di dalam kelas juga } \\
\text { diterapkan dalam pembelajaran melalui daring } \\
\text { (online) }\end{array}$ & $\begin{array}{l}\text { Dari total } 33 \text { responden, sebanyak } \\
66,7 \% \text { mahasiswa menjawab iya, } \\
27,3 \% \text { menjawab mungkin/netral, dan } \\
\text { sisanya } 6 \% \text { menjawab tidak. }\end{array}$ \\
\hline 2 & $\begin{array}{l}\text { Metode langsung yang digunakan dalam } \\
\text { pembelajaran mata kuliah Kemahiran } \\
\text { Berbicara Bahasa Arab sudah efektif untuk } \\
\text { mendapatkan hasil yang maksimal selama } \\
\text { proses pembelajaran melalui daring (online) }\end{array}$ & $\begin{array}{l}\text { Dari total } 33 \text { responden, sebanyak } \\
\text { 18,2\% mahasiswa menjawab iya, } \\
75,8 \% \text { menjawab mungkin/netral, dan } \\
\text { sisanya } 6 \% \text { menjawab tidak. }\end{array}$ \\
\hline 3 & $\begin{array}{l}\text { Kendala yang terjadi seperti jaringan internet } \\
\text { yang lemah dan fokus mahasiswa yang kurang } \\
\text { selama proses pembelajaran melalui daring }\end{array}$ & $\begin{array}{l}\text { Dari total } 33 \text { responden, sebanyak } \\
72,7 \% \text { mahasiswa menjawab iya, }\end{array}$ \\
\hline
\end{tabular}




\begin{tabular}{|c|c|c|}
\hline & $\begin{array}{l}\text { (online) membuat mahasiswa kesulitan } \\
\text { menjalani proses pembelajaran }\end{array}$ & $\begin{array}{l}24,2 \% \text { menjawab mungkin/netral, dan } \\
\text { sisanya } 3,1 \% \text { menjawab tidak }\end{array}$ \\
\hline & $\begin{array}{l}\text { Proses belajar mengajar melalui daring (online) } \\
\text { lebih mudah dibandingkan belajar mengajar } \\
\text { tatap muka di kelas }\end{array}$ & $\begin{array}{l}\text { Dari total } 33 \text { responden, sebanyak } \\
15,2 \% \text { mahasiswa menjawab iya, } \\
21,2 \% \text { menjawab mungkin/netral, dan } \\
\text { sisanya } 63,6 \% \text { menjawab tidak }\end{array}$ \\
\hline & $\begin{array}{l}\text { Mata kuliah Kemahiran Berbicara Bahasa Arab } \\
\text { secara daring (online) menambah pengetahuan } \\
\text { mahasiswa }\end{array}$ & $\begin{array}{l}\text { Dari total } 33 \text { responden, sebanyak } \\
15,2 \% \text { mahasiswa menjawab iya, } \\
78,8 \% \text { menjawab mungkin/netral, dan } \\
\text { sisanya } 6 \% \text { menjawab tidak }\end{array}$ \\
\hline & $\begin{array}{l}\text { Alat bantu seperti laptop dan headset, } \\
\text { memberikan efektivitas yang lebih pada mata } \\
\text { kuliah Kemahiran Berbicara Bahasa Arab } \\
\text { selama pembelajaran melalui daring (online) }\end{array}$ & $\begin{array}{l}\text { Dari total } 33 \text { responden, sebanyak } \\
57,6 \% \text { mahasiswa menjawab iya, } \\
33,3 \% \text { menjawab mungkin/netral, dan } \\
\text { sisanya } 9,1 \% \text { menjawab tidak }\end{array}$ \\
\hline
\end{tabular}

Pertanyaan pertama mengenai penerapan metode pembelajaran dalam mata kuliah Kemahiran Berbicara Bahasa Arab konvensional (di dalam kelas) dalam pembelajaran melalui daring (online). Metode pembelajaran bahasa yang digunakan akan sangat mempengaruhi siswa dalam mengasah kemampuan berbahasa. Dalam pembelajaran tatap muka (konvensional), dosen dan mahasiswa bertemu secara langsung yang mana dalam praktek berbicara Bahasa Arab dapat dilakukan secara langsung, sehingga dosen dapat mengukur perkembangan kemahiran berbicara bahasa Arab dari masing-masing siswa. Kuliah daring yang dilaksanakan dalam mata kuliah Kemahiran Berbicara Bahasa Arab tentu memerlukan praktik dan pengawasan dosen. Maka, pertanyaan ini sangat penting untuk ditelaah dalam penelitian ini.

Pertanyaan kedua mengenai efektifitas metode langsung yang digunakan dalam pembelajaran mata kuliah Kemahiran Berbicara Bahasa Arab dalam mendapatkan hasil yang maksimal selama proses. Mahasiswa sebagai pembelajar tentu merasakan perbedaan dalam proses pembelajaran secara daring. Meskipun proses pembelajaran dilakukan dengan cara, metode, dan situasi yang berbeda, peneliti perlu memahami apakah mahasiswa dapat berproses secara maksimal dalam mata kuliah Kemahiran Berbicara Bahasa Arab untuk mengetahui tingkat efektifitas pembelajaran daring dalam mata kuliah ini.

Pertanyaan selanjutnya terkait kendala yang dialami oleh mahasiswa selama proses pembelajaran melalui daring (online). Ketika mahasiswa memahami solusi dari kendala yang terjadi selama proses pembelajaran, maka mahasiswa tentu dapat mengatasinya dengan baik. Akan tetapi apabila mahasiswa merasa sulit dalam mengatasi hal tersebut, tentu mahasiswa akan merasa kesulitan 
dalam meningkatkan kemahiran berbicara bahasa Arab melalui kuliah daring. Maka, hal ini perlu dianalisis karena merupakan salah satu faktor yang mempengaruhi efektifitas pembelajaran daring.

Pertanyaan selanjutnya mengenai kemudahan kuliah daring daripada pembelajaran tatap muka di kelas. Pertanyaan ini diajukan untuk mengukur seberapa nyaman dan efektif pembelajaran daring dalam mata kulilah Kemahiran Berbicara Bahasa Arab, khususnya bagi mahasiswa program studi Bahasa dan Kebudayaan Arab Universitas Al-Azhar Indonesia.

Pertanyaan kelima, apakah mata kuliah kemahiran berbicara bahasa Arab secara daring (online) menambah pengetahuan mahasiswa. Suatu proses pembelajaran dapat dikatakan efektif ketika hasil dari proses pembelajaran tersebut dapat ditangkap dengan baik dan kemampuan peserta didik meningkat.

Pertanyaan terakhir mengenai efektifitas alat bantu seperti laptop, headset, dan lain sebagainya dalam mata kuliah Kemahiran Berbicara Bahasa Arab selama pembelajaran melalui daring (online). Karena proses pembelajaran tidak dapat dilaksanakan dalam satu tempat yang sama, maka pertanyaan ini perlu diajukan untuk mengukur tingkat efektifitas dan kesuksesan pembelajaran daring.

Tabel 2. Perhitungan Skala Likert

\begin{tabular}{ccc}
\hline $\begin{array}{c}\text { No } \\
\text { Angket }\end{array}$ & Indeks Prestasi & Keterangan \\
\hline 1 & $85,14 \%$ & IYA \\
2 & $69,3 \%$ & IYA \\
3 & $88,11 \%$ & IYA \\
4 & $49,5 \%$ & MUNGKIN/NETRAL \\
5 & $68,31 \%$ & IYA \\
6 & $81,18 \%$ & IYA \\
\hline
\end{tabular}

Tabel 3. Ketentuan Skor Tertinggi, Skor Terendah dan Interval Rentangan Skor Kuesioner

\begin{tabular}{ccc}
\hline No & Deskripsi & Jumlah \\
\hline 1 & Skor Terendah (x) & 33 \\
2 & Skor Tertinggi (y) & 99 \\
3 & Interval (I) & 33.33 \\
\hline
\end{tabular}

Tabel 4. Kriteria Interpretasi Skor

\begin{tabular}{ccc}
\hline No & Deskripsi & Jumlah \\
\hline 1 & TIDAK & $0 \%-33,32 \%$ \\
2 & MUNGKIN/NETRAL & $33,33 \%-66.65 \%$
\end{tabular}


Pendapat responden pada pertanyaan pertama yaitu, "Apakah metode yang digunakan dosen dalam mata Kuliah Kemahiran Berbicara Bahasa Arab yang biasa digunakan di dalam kelas diterapkan dalam pembelajaran daring (online)?", sebagaimana diagram yang telah dipaparkan di atas dapat dilihat bahwa 66,7 \% memilih jawaban iya, 27,3\% memilih jawaban mungkin, dan 6\% memilih jawaban tidak.

Dari ke-33 responden yang menjawab lebih dari setengah, responden merasakan penerapan metode yang sama dalam pembelajaran di kelas secara offline maupun secara daring (online). Hal ini menunjukkan bahwa proses pembelajaran daring tidak mengubah metode pembelajaran Kemahiran Berbicara Bahasa Arab secara drastis. Metode pembelajaran yang sama tentu memudahkan mahasiswa karena mahasiswa tidak perlu menyesuaikan diri dengan metode baru. Hasilnya adalah metode pembelajaran yang digunakan dalam pembelajaran daring cukup efektif.

Pendapat responden pada pertanyaan kedua yaitu, “Apakah metode langsung yang digunakan dalam pembelajaran mata kuliah Kemahiran Berbicara Bahasa Arab sudah efektif untuk mendapatkan hasil yang maksimal selama proses pembelajaran melalui daring (online)?”, sebagaimana diagram yang telah dipaparkan di atas dapat dilihat bahwa 75,8\% memilih jawaban mungkin/netral untuk pertanyaan mengenai keefektifan pembelajaran muhadatsah secara daring.

Tidak dapat dipungkiri bahwa hanya 18,2\% yang memilih jawaban iya, dan 6\% menjawab tidak karena masih banyak kesulitan belajar berbicara bahasa Arab melalui daring (online). Dalam hal ini sebagian besar mahasiswa merasa belum yakin apakah pembelajaran daring dapat memberikan hasil yang maksimal atau tidak. Hasilnya adalah efektifitas pembelajaran daring dalam memberikan hasil yang maksimal dan meningkatkan kemampuan mahasiswa belum dapat dicapai sepenuhnya.

Pendapat responden pada pertanyaan ketiga yaitu, “Apakah kendala seperti jaringan internet yang lemah dan fokus mahasiswa kurang, yang terjadi selama proses pembelajaran melalui daring (online) membuat mahasiswa kesulitan menjalani proses pembelajaran?”, sebagaimana diagram yang telah dipaparkan di atas dapat dilihat bahwa 24,2 \% memilih jawaban mungkin/netral, sebanyak $72,7 \%$ memilih jawaban iya, dan 3,1\% menjawab tidak. Pembelajaran kemahiran berbicara bahasa Arab melalui daring (online) memiliki banyak kendala yang dirasakan oleh mahasiswa terutama jaringan internet yang lemah serta fokus mahasiswa yang kurang. Hasil dari pendapat responden mengenai pertanyaan ketiga menunjukkan bahwa pembelajaran kemahiran berbicara, lebih tepat pelaksanaannya secara offline atau tatap muka secara langsung. 
Pendapat responden pada pertanyaan keempat yaitu, “Apakah proses belajar mengajar melalui daring (online) lebih mudah dibandingkan belajar mengajar tatap muka di kelas?”, sebagaimana diagram yang telah dipaparkan di atas dapat dilihat bahwa 63,6\% memilih jawaban tidak, 21,2\% memilih jawaban mungkin/netral, dan 15,2\% memilih jawaban iya. Dibanding dengan belajar daring (online) mahasiswa lebih memilih bertatap muka dalam kelas (offline) karena lebih memudahkan mereka dalam bertanya secara langsung kepada pengajar jika menemukan hal yang menurut mereka sulit. Selain itu, praktik berbicara bahasa Arab dapat dilaksanakan secara langsung.

Pendapat responden pada pertanyaan kelima yaitu, "Apakah mata kuliah Kemahiran Berbicara Bahasa Arab secara daring (online) menambah pengetahuan mahasiswa?”, sebagaimana diagram yang telah dipaparkan di atas dapat dilihat bahwa 78,8\% memilih jawaban mungkin/netral, 15,2\% memilih jawaban iya, dan $6 \%$ memilih jawaban tidak. Responden masih merasa bingung apakah mata kuliah Kemahiran Berbicara Bahasa Arab ini dapat menambah pengetahuan mahasiswa atau tidak melalui kelas daring (online). Bagi mereka, mata kuliah tersebut hanya dapat menambah kosakata dalam bahasa Arab dan prakteknya lebih terbatas daripada pembelajaran tatap muka (secara langsung).

Pendapat responden pada pertanyaan terakhir yaitu, "Apakah alat bantu seperti laptop dan headset memberikan efektivitas yang lebih pada mata kuliah Kemahiran Berbicara Bahasa Arab selama pembelajaran daring (online)?", sebagaimana diagram yang telah dipaparkan di atas dapat dilihat bahwa 57,6\% memilih jawaban iya, 33,3\% memilih jawaban netral/mungkin, dan 9,1\% memilih jawaban tidak. Dominasi pada responden yang menjawab iya lebih banyak karena pada saat pembelajaran jarak jauh diadakan, alat bantu seperti laptop dan headset sangat dibutuhkan pada pembelajaran mata kuliah Kemahiran Berbicara Bahasa Arab, pada responden yang menjawab netral karena pegajar menggunakan alat bantu via WhatsApp untuk berlangsungnya pembelajaran jarak jauh mata kuliah kemahiran berbicara bahasa Arab.

\section{KESIMPULAN}

Berdasarkan hasil penelitian terhadap 33 mahasiswa dan mahasiswi angkatan 2019 Program Studi Bahasa dan Kebudayaan Arab di Universitas Al Azhar Indonesia, dapat disimpulkan bahwa penelitian yang penulis lakukan mengenai tingkat efektivitas pembelajaran daring (online) pada mata kuliah Kemahiran Berbicara Bahasa Arab di Universitas Al Azhar Indonesia cukup baik. Selain itu, pembelajaran daring pada mata kuliah Kemahiran Berbicara Bahasa Arab di Universitas Al Azhar Indonesia memiliki pengaruh yang cukup baik. Hal ini dapat dibuktikan dengan melihat banyaknya mahasiswa yang setuju dengan metode yang diterapkan dalam pembelajaran daring tersebut. Mereka 
juga merasa sangat terbantu dengan penggunaan alat bantu komuikasi seperti WhatsApp, Zoom, Youtube, dan sebagainya. Oleh karena itu, pembelajaran pada mata kuliah kemahiran berbicara bahasa Arab melalui daring (online) juga terlaksanakan dengan lancar. Kelebihan dalam menggunakan media dan alat bantu komunikasi di atas ialah mampu menjangkau kegiatan mahasiswa dan pengajar dalam berkomunikasi jarak jauh dan mendapatkan wawasan referensi lebih banyak saat mengerjakan tugas yang diberikan oleh pengajar. Kekurangan dalam media ini adalah kurang fokusnya mahasiswa karena banyak iklan yang lewat saat penggunaan media tersebut.

\section{DAFTAR PUSTAKA}

Churton, M. W. (2006). Principles of E-learning and On-line Teaching. Jurnal Pendidikan Terbuka Dan Jarak Jauh, 7(1), 15-33. http://simpen.lppm.ut.ac.id/htmpublikasi/churton.pdf

Dafalla, S., \& Ahmed, M. (2017). Difficulties and Challenges in Teaching and Learning Speaking at Advanced Level. 38-16 مجلة جامعة السلام - العدد الخامس - دسمبير 2017 م.

Haron, S. C. (2012). Speaking good Arabic: learners? perceptions. Journal of Education and Practice, 3(7), 151-158. http://irep.iium.edu.my/25487/

Iqbal, Sofia, \& Sohail, S. (2021). Challenges of Learning During the Covid-19 Pandemic. Journal of Gandhara Medical and Dental Science, 8(2), 1. https://doi.org/10.37762/jgmds.8-2.215

M.M Mukaka. (2012). Statistics Corner: A Guide to Appropriate Use of Correlation Coefficient. Malawi Medical Journal, 24(3), 69-71. https://pubmed.ncbi.nlm.nih.gov/23638278/

Mahyoob, M. (2020). Challenges of e-Learning during the COVID-19 Pandemic Experienced by EFL Learners. Arab World English Journal, 11(4), 351-362. https://doi.org/10.24093/awej/vol11no4.23

Marlius, Y., Bambang, B., \& Wirman, M. (2021). The Efforts to Improve Students' Arabic Speaking Skills Through Language Environment Activation: A Study of Phenomenology. Al-Ta'rib : Jurnal Ilmiah Program Studi Pendidikan Bahasa Arab IAIN Palangka Raya, 9(1), 35-48. https://doi.org/10.23971/altarib.v9i1.2585

Rosyadi, F. I., \& Ilmi, M. U. (2021). E-Learning: An Implementation for Arabic Learning During the Covid-19 Pandemic. ALSUNIYAT: Jurnal Penelitian Bahasa, Sastra, Dan Budaya Arab, 4(1), 47-57. https://doi.org/10.17509/alsuniyat.v4i1.32259

Sadikin, A., \& Hamidah, A. (2020). Pembelajaran Daring di Tengah Wabah Covid-19. Biodik, 6(2), 109-119. https://doi.org/10.22437/bio.v6i2.9759 
Syahputri, V. N., Rahma, E. A., Setiyana, R., Diana, S., \& Parlindungan, F. (2020). Online learning drawbacks during the Covid-19 pandemic: A psychological perspective. EnJourMe (English Journal of Merdeka): Culture, Language, and Teaching of English, 5(2), 108-116. https://doi.org/10.26905/enjourme.v5i2.5005

Wargadinata, W. W. (2020). Mediated Arabic Language Learning for Arabic Students of Higher Education in COVID-19 Situation. Izdihar : Journal of Arabic Language Teaching, Linguistics, and Literature, 3(1), 59-78. https://doi.org/10.22219/jiz.v3i1.11862

Warschauer, M. (2001). Computer Assisted Language Learning.

Yaqub, M. T. (2012). Developing Speaking Skill in Arabic Learners : A Proposal for Integration of Product and Process Approaches. European Scientific Jounal, 8(29), 140-149. 
EFEKTIVITAS PEMBELAJARAN DARING PADA MATA KULIAH KEMAHIRAN BERBICARA ...

Ghina Kania Rahmah 